\title{
SIKAP ANGGOTA DPRD KABUPATEN BANYUMAS TERHADAP PARTISIPASI MASYARAKAT DALAM PEMBENTUKAN PERATURAN DAERAH Oleh: Noer Indriati ${ }^{1}$, MuhammadTaufiq ${ }^{2}$, Wismaningsih ${ }^{3}$
}

\begin{abstract}
The community has the authority to regulate and resolve the matter themselves according to local aspirations. It is clear that the position of trying to reassert the community is the subject of autonomy is not the object of autonomy. The decentralization policy explicitly also uncover the essence of autonomy as authorities set up and take care of his household. The aim's to analyze the against public participation in rulemaking. The method of the research is socio legal approach, the data sources used are primary data and secondary data, with analysis in quantitative diskriptif.

Results of the research as follows: the participation of youth in the formation of Regulatory Region of Pilkades 50\% of respondents indicate a very high participation,. Participation of mothers PKK/dawis high participation 43.54 and the general public towards $35.51 \%$ showed very high participation, $60.98 \%$ of respondents participated in height and $2.91 \%$ of respondents indicating participation is quite high. The participation of notable clerics against Perda Pilkades $42.4 \%$ of respondents indicate a very high participation, $46.40 \%$ of respondents indicate high participation and $7 \%$ of respondents indicating participation is quite high.
\end{abstract}

Keywords: attitude, participation of civilation, the district act

\begin{abstract}
ABSTRAK
Masyarakat mempunyai kewenangan untuk mengatur dan menyelesaikan urusannya sendiri sesuai aspirasi setempat. Hal ini mempertegas bahwa posisi masyarakat merupakan subjek otonomi bukan objek otonomi. Secara eksplisit kebijakan desentralisasi juga mengungkap hakekat otonomi sebagai wewenang mengatur dan mengurus rumah tangganya. Tujuan untuk menganalisa partisipasi masyarakat dalam pembuatan Peraturan Daerah. Metode pendekatan yurudis sosiologis, sumber data yang digunakan adalah data primer dan data sekunder, dengan analisa secara diskriptif kuantitatif.

Hasil penelitian sebagai berikut: partisipasi pemuda dalam pembentukan Peraturan Daerah tentang Pilkades 50\% responden menunjukkan partisipasi yang sangat tinggi, $20 \%$ partisipasi tinggi dan 30\% menunjukkan partisipasi cukup tinggi. Partisipasi ibu-ibu PKK/dawis terhadap Perda pilkades menunjukkan sangat tinggi 29,95\%, partisipasi tinggi 43,54 dan responden menunjukkan partisipasi cukup tinggi 4,04\%. Partisipasi masyarakat umum terhadap Perda pilkades $35,51 \%$ menunjukkan partisipasi sangat tinggi, $60,98 \%$ responden berpartisipasi tinggi dan 2,91\% responden menunjukkan partisipasi cukup tinggi. Partisipasi tokoh ulama terhadap Perda Pilkades $42,4 \%$ responden menunjukkan partisipasi sangat tinggi, 46,40\% responden menunjukkan partisipasi tinggi dan $7 \%$ responden menunjukkan partisipasi cukup tinggi.
\end{abstract}

Kata Kunci: sikap, partisipasi masyarakat, Peraturan Daerah.

\footnotetext{
${ }^{1}$ Alamat Koresponden sunoboputri40@gmail.com

2 Alamat Koresponden taufiq1960@yahoo.co.id

${ }^{3}$ Alamat Koresponden wismaningsih10@gmail.com
} 


\section{7 | Jurnal Idea Hukum \\ Vol. 5 No. 1 Maret 2019 \\ Magister Hukum Fakultas Hukum Universitas Jenderal Soedirman}

\section{A. Latar Belakang Masalah}

Kebijakan desentralisasi di Indonesia menghendaki penyelenggaraan pemerintahan daerah yang berbasis pada partisipasi masyarakat. Partisipasi menjadi konsep penting karena masyarakat ditempatkan sebagai subjek utama dalam penyelenggaraan otonomi daerah.

Partisipasi

masyarakat

mempunyai dua fungsi yaitu: sebagai sarana swa-edukasi kepada masyarakat mengenai berbagai persoalan publik. Partisipasi masyarakat dalam fungsi ini tidak akan mengancam stabilitas politik dan seyogyanya berjalan di semua jenjang pemerintahan, dan sebagai sarana untuk menampilkan keseimbangan kekuasaan antara masyarakat dan pemerintah sehingga kepentingan dan pengetahuan masyarakat dapat terserap dalam agenda pemerintahan.

$\begin{array}{ccc}\text { Peraturan Daerah dalam } & \text { daerah } \\ \text { penyelenggaraan otonomi } & \text { dangat }\end{array}$
penting karena apabila dikembalikan kepada konsep otonomi daerah mengandung arti zelfbestuur (pemerintahan sendiri) dan juga zelfwetgeving (membuat perda-perda). Kewenangan mengatur mengandung arti bahwa daerah berhak membuat keputusan hukum berupa peraturan perundang-undangan, yang nomenklaturnya disebut Peraturan
Daerah. Dengan demikian, kehadiran atau keberadaan Peraturan Daerah menjadi sesuatu yang mutlak dalam mengatur urusan rumah tangga daerah, dalam suatu negara kesatuan yang tetap menempatkan hubungan Pusat dan Daerah yang bersifat subordinasi dan independen. ${ }^{4}$

Pemerintahan daerah secara yuridis normatif berhak menetapkan Peraturan Daerah dalam penyelenggaraan otonomi daerah dengan tujuan meningkatkan kesejahteraan masyarakat, pelayanan umum, dan daya saing daerah. Pemerintahan daerah dalam menjalankan urusan pemerintahan yang menjadi kewenangan daerah, menjalankan otonomi seluas-luasnya untuk mengatur dan mengurus sendiri urusan pemerintahan berdasarkan asas otonomi dan tugas pembantuan.

Berdasarkan sistem hukum yang dianut Indonesia, suatu produk perundang-undangan tidak boleh bertentangan dengan peraturan perundang-undangan yang lebih tinggi. Berdasarkan kewenangan pemerintah daerah terkait dengan otonomi daerah, maka semua kewenangan daerah, baik kewenangan yang menjadi urusan wajib dan urusan pilihan dari masing-masing

4 Tim Peneliti Universitas Hasanuddin, 2009, Hasil Penelitian: Esensi Dan Urgensitas Peraturan Daerah Dalam Pelaksanaan Otonomi Daerah, Universitas Hasanuddin bekerjasama dengan Dewan Perwakilan Daerah Republik Indonesia, Makasar, hal. 6. 
pemerintahan daerah provinsi, kabupaten/kota, dapat menjadi materi muatan Peraturan Daerah sepanjang tidak bertentangan dengan peraturan perundang-undangan yang lebih tinggi dan kepentingan umum. ${ }^{5}$

Perlunya sistem otonomi daerah disadari oleh para pendiri negara Republik Indonesia ketika menyusun Undang-Undang Dasar 1945, mempertimbangkan letak geografis dan kondisi sosiologis masyarakat Indonesia yang tersebar di berbagai pulau dan terdiri atas berbagai suku, agama, ras, dan golongan. ${ }^{6}$ Konsep otonomi daerah kemudian diatur dan dituangkan dalam konstitusi pertama yaitu Pasal 18 Undang-Undang Dasar Negara Republik Indonesia tahun 1945.

Hasil penelitian ini akan direkomendasikan terhadap partisipasi masyarakat dalam pembuatan Peraturan Daerah, sehingga tidak dapat mengabaikan kewajibannya dalam menjaring dan merespon partisipasi masyarakat dalam proses pembentukan Peraturan Daerah dan di pihak lain masyarakat dapat menuntut secara efektif kepada para wakilnya yang telah

\footnotetext{
${ }^{5}$ Ibid., hal. 9

6 Kementerian Hukum dan Hak Asasi Manusia Republik Indonesia, Direktorat Jenderal Peraturan Perundang-undangan, Direktorat Fasilitasi Perancangan Peraturan Daerah, 2011, Panduan Praktis Memahami Perancangan Peraturan Daerah Edisi Kelima, Direktorat Jenderal Peraturan Perundang-undangan, Jakarta, hal.1.
}

dipilih menjadi anggota dalam Dewan

Perwakilan Rakyat Daerah.

\section{B. Metode Penelitian}

Pendekatan yang digunakan dalam penelitian ini adalah metode kuantitatif dengan pendekatan yurudis sosiologis (socio legal approach). Pendekatan yuridis sosiologis dimaksudkan sebagai penerapan dan pengkajian hubungan aspek hukum dengan aspek non hukum dalam bekerjanya hukum di dalam kenyataanya (inconcreto), sehingga hukum tidak dipandang sebagai norma yang tertutup dan otonom, namun memiliki keterkaitan yang erat dengan variabel-variabel non hukum yang dalam hal ini pendidikan, latar belakang politik dan cara partisipasi.

Sumber data primer adalah pendapat langsung melalui kuesioner dari sikap dewan yang dalam hal ini meliputi para anggota DPRD Kabupaten Banyumas rencana diambil data sebesar $20 \%$ dari jumlah 50 orang. Data yang diperoleh hanya 11 orang dari 50 orang anggota. Responden dari pemuda sebanyak 25 orang, ibu-ibu PKK sebanyak 25 orang dan masyarakat umum sebanyak 25 orang di Desa Kalisalak, Kecamatan Kedungbanteng, Kabupaten Banyumas, sedangkan ulama dari beberapa wilayah yang dikumpulkan di Pondok Al Jauhariah, Kecamatan Sokaraja, Kabupaten Banyumas sebanyak 4 (empat) orang. 
1389 | Jurnal Idea Hukum

Vol. 5 No. 1 Maret 2019

Magister Hukum Fakultas Hukum Universitas Jenderal Soedirman

Responden yang ditentukan tidak selalu hadir dengan jumlah seperti yang dikehendaki.

Sumber data sekunder, yaitu berupa peraturan perundang-undangan yang berkaitan dengan materi penelitian, buku/literatur dan jurnaljurnal, makalah serta dari internet yang berkaitan dengan pokok permasalahan. Metode analisis yang digunakan deskriptif kuantitatif.

\section{Hasil dan Pembahasan}

Pada dasarnya Undang-undang No. 9 Tahun 2015 sebagai Perubahan Kedua Atas Undang-Undang Nomor 23 Tahun 2014 Tentang Pemerintahan Daerah, di era reformasi membawa semangat dalam penyelenggaraan pemerintahan daerah secara partisipatif. Partisipasi menjadi konsep penting karena masyarakat ditempatkan sebagai subjek utama dalam penyelenggaraan otonomi daerah, arti penting partisipasi terletak pada fungsi dan manfaatnya.

\section{Struktur dan Pembentukan Sikap}

Dilihat dari strukturnya sikap terdiri atas tiga komponen yang saling menunjang, yaitu komponen kognitif, komponen afektif, dan komponen konatif. Komponen kognitif berupa apa yang dipercayai oleh subjek pemilik sikap. Komponen kognitif berisi kepercayaan seseorang mengenai objek sikap. Kepercayaan datang dari apa yang telah dilihat atau diketahui. Sekali kepercayaan itu telah terbentuk, maka akan menjadi dasar pengetahuan seseorang mengenai apa yang dapat diharapkan dan apa yang tidak dapat diharapkan dari objek tertentu.

Komponen afektif menyangkut masalah emosional subjektif seseorang terhadap suatu objek sikap. Secara umum, komponen ini disamakan dengan perasaan yang dimiliki terhadap sesuatu. Pada umumnya, reaksi emosional yang merupakan komponen afektif ini banyak ditentukan oleh kepercayaan atau apa yang dipercayai sebagai benar bagi objek termaksud.

Komponen perilaku atau komponen konatif dalam sikap menunjukkan bagaimana perilaku atau kecenderungan berperilaku yang ada di dalam diri seseorang berkaitan dengan objek sikap yang dihadapinya. Asumsi dasar adalah bahwa kepercayaan dan perasaan mempengaruhi perilaku, maksudnya, bagaimana orang akan berperilaku dalam situasi tertentu dan terhadap stimulus tertentu akan banyak ditentukan oleh bagaimana kepercayaan dan perasaannya terhadap stimulus tersebut. Kecenderungan berperilaku secara konsisten, 
selaras dengan kepercayaan dan perasaan ini membentuk sikap individual, karena itu logis untuk mengharapkan bahwa sikap seseorang akan dicerminkannya dalam bentuk perilaku terhadap objek.

Sikap sosial terbentuk dari adanya interaksi sosial yang dialami individu. Interaksi sosial mengandung arti lebih dari pada sekedar adanya kontrak sosial dan hubungan antarindividu sebagai anggota kelompok sosial. Terjadi hubungan saling mempengaruhi diantara individu yang satu dengan yang lain dalam interaksi sosial, terjadi hubungan timbal balik yang turut mempengaruhi pola perilaku masing-masing individu sebagai anggota masyarakat. Lebih lanjut, interaksi sosial tu meliputi hubungan antara individu dengan lingkungan fisik maupun lingkungan psikologis di sekelilingnya.

Individu dalam interaksi sosialnya, bereaksi membentuk pola sikap tertentu terhadap berbagai objek psikologis yang dihadapinya. Di antara berbagai faktor yang mempengaruhi pembentukan sikap adalah pengalaman pribadi, kebudayaan, orang lain yang dianggap penting, media masa, institusi atau lembaga pendidikan dan lembaga agama, serta faktor emosi dalam diri individu.

\section{Pengertian \\ Masyarakat}

Partisipasi

Partisipasi merupakan aspirasi dari berbagai pihak dapat dijadikan sebuah pertimbangan bagi seorang pengambil keputusan untuk memutuskan sebuah keputusan. Kearifan dalam merespon dinamika perubahan sosial merupakan landasan bagi pemerintah guna menjalankan amanat rakyat, yang dilakukan melalui kebijakan-kebijakan yang berfokus pada rakyat. Untuk itu kapasitas lembaga-lembaga pemerintahan perlu ditingkatkan untuk mendorong terwujudnya civil society yang utuh dan otonom pada masyarakat.

Menurut Djalal dan Supriadi menjelaskan bahwa makna partisipasi adalah pembuatan keputusan dengan menyarankan kelompok atau masyarakat yang ikut terlibat dalam bentuk penyampaian saran dan pendapat, bahan, keterampilan, barang dan jasa. ${ }^{7}$ Pendapat lain diutarakan oleh Echols \& Shadily, bahwa pengertian partisipasi adalah suatu

\footnotetext{
${ }^{7}$ Teguh Yuwono, 2001, Manajemen Otonomi Daerah : Membangun Daerah Berdasarkan Paradigma Baru, Semarang: Ciyapps Diponegoro Universiti, hal 201-202
} 


\section{1 | Jurnal Idea Hukum}

Vol. 5 No. 1 Maret 2019

Magister Hukum Fakultas Hukum Universitas Jenderal Soedirman

kegiatan untuk membangkitkan perasaan dan diikutsertakan atau ambil bagian dalam kegiatan suatu organisasi. ${ }^{8} \quad \mathrm{Di}$ dalam bukunya Sumaryadi menjelaskan mengenai pengertian partisipasi sebagai peran serta seseorang atau kelompok masyarakat dalam proses pembangunan baik dalam bentuk pernyataan maupun dalam bentuk kegiatan dengan memberi masukan seperti: ${ }^{9}$
a. Pikiran.
b. Tenaga.
c. Waktu.
d. Keahlian (skill).
e. Modal (materi). menikmati hasil-hasil pembangunan.
f. Ikut memanfaatkan dan

Berdasarkan dari beberapa pendapat para ahli dan pakar tersebut di atas, maka jelas bahwa keterlibatan masyarakat secara langsung dalam proses pembangunan adalah suatu langkah awal guna keberhasilan suatu pembangunan.

Definisi ini yang paling tepat dan sesuai dengan Dewan Perwakilan Rakyat Daerah sebagai wakil dari masyarakat, yaitu yang diutarakan oleh Davis, yang mengatakan partisipasi adalah

8 Loekman Soetrisno, 2000, Menuju Masyarakat Partisipatif, Yogyakarta: Kanisius, hal. 419

${ }^{9}$ I Nyoman Sumaryadi, 2005, Efektivitas Implementasi Kebijkan Otonomi Daerah, Jakarta: Citra Utama, hal 46. keterlibatan mental dan emosional seseorang atau individu dalam situasi kelompok yang mendorong dia untuk berkontribusi terhadap tujuan kelompok dan mempertanggung-jawabkan keterlibatannya. $^{10}$

\section{Suatu Peraturan Daerah}

tidak hanya berfungsi untuk mengatur masyarakat namun juga memiliki fungsi strategis lain yaitu memberikan perlindungan terhadap hak-hak rakyat, terjadinya perubahan sosial dan meningkatkan pemberdayaan masyarakat. Peraturan Daerah atas inisiatif Dewan Perwakilan Rakyat Daerah yang telah disahkan tersebut, merupakan cerminan dari kualitas, kemauan dan komitmen anggota DPRD Kabupaten Banyumas dalam mengemban tugas legislasi. Dalam penyusunan draft rancangan Peraturan Daerah atas inisiatif DPRD, dengan melibatkan partisipasi masyarakat melalui public hearing dan tinjauan lapangan. Peraturan Daerah ini bertujuan untuk kelancaran dan ketertiban pelaksanaan pemilihan Kepala Desa.

Pada hakikatnya Otonomi Daerah diberikan kepada rakyat sebagai satu kesatuan masyarakat

${ }^{10}$ Keith Davis, 2000, Perilaku Dalam Organisasi, Edisi ketujuh, Jakarta: Erlangga, hal. 142 
hukum yang diberi kewenangan untuk mengatur dan mengurus sendiri Urusan Pemerintahan yang diberikan oleh Pemerintah Pusat kepada Daerah dan dalam pelaksanaannya dilakukan oleh Kepala Daerah dan DPRD dengan dibantu oleh Perangkat Daerah. Urusan Pemerintahan yang diserahkan ke Daerah berasal dari kekuasaan pemerintahan yang ada ditangan Presiden.

Konsekuensi dari negara kesatuan adalah tanggung jawab akhir pemerintahan ada ditangan Presiden. Agar pelaksanaan Urusan Pemerintahan yang diserahkan ke Daerah berjalan sesuai dengan kebijakan nasional maka Presiden berkewajiban untuk melakukan pembinaan dan pengawasan terhadap penyelenggaraan Pemerintahan Daerah. Presiden sebagai pemegang kekuasaan pemerintahan dibantu oleh menteri negara dan setiap menteri bertanggung atas Urusan Pemerintahan tertentu dalam pemerintahan.

$$
\text { Sebagian }
$$

Urusan

Pemerintahan yang menjadi tanggung jawab menteri tersebut sesungguhnya diotonomikan ke Daerah. Konsekuensi menteri sebagai pembantu Presiden adalah kewajiban menteri atas nama
Presiden untuk melakukan pembinaan dan pengawasan agar penyelenggaraan Pemerintahan Daerah berjalan sesuai dengan ketentuan peraturan perundangundangan. Agar tercipta sinergi antara Pemerintah Pusat dan Daerah, kementerian/lembaga pemerintah non-kementerian berkewajiban membuat norma, standar, prosedur, dan kriteria (NSPK) untuk dijadikan pedoman bagi Daerah dalam menyelenggarakan Urusan Pemerintahan yang diserahkan ke Daerah dan menjadi pedoman bagi kementerian/lembaga pemerintah non-kementerian untuk melakukan pembinaan dan pengawasan.

$$
\text { Presiden melimpahkan }
$$
kewenangan kepada Menteri sebagai koordinator pembinaan dan pengawasan yang dilakukan oleh kementerian/lembaga pemerintah non-kementerian terhadap penyelenggaraan Pemerintahan Daerah. Kementerian/lembaga pemerintah non-kementerian melakukan pembinaan dan pengawasan yang bersifat teknis, sedangkan Kementerian melaksanakan pembinaan dan pengawasan yang bersifat umum. Mekanisme tersebut diharapkan mampu menciptakan harmonisasi antar kementerian/lembaga pemerintah 
1393 | Jurnal Idea Hukum

Vol. 5 No. 1 Maret 2019

Magister Hukum Fakultas Hukum Universitas Jenderal Soedirman

non-kementerian dalam melakukan

pembinaan dan pengawasan

penyelenggaraan Pemerintahan

Daerah secara keseluruhan.

Berbeda

dengan

penyelenggaraan pemerintahan di pusat yang terdiri atas lembaga eksekutif, legislatif, dan yudikatif, penyelenggaraan Pemerintahan Daerah dilaksanakan oleh DPRD dan Kepala Daerah. Dewan Perwakilan Rakyat Daerah dan Kepala Daerah berkedudukan sebagai unsur penyelenggara pemerintahan daerah yang diberi mandat rakyat untuk melaksanakan Urusan Pemerintahan yang diserahkan Kepada Daerah. Dengan demikian maka DPRD dan Kepala Daerah berkedudukan sebagai mitra sejajar yang mempunyai fungsi yang berbeda. Dewan Perwakilan Rakyat Daerah mempunyai fungsi pembentukan Perda, anggaran dan pengawasan, sedangkan Kepala Daerah melaksanakan fungsi pelaksanaan atas Perda dan kebijakan Daerah. Dewan Perwakilan Rakyat Daerah dan Kepala Daerah dibantu oleh Perangkat Daerah dalam mengatur dan mengurus Urusan Pemerintahan yang menjadi kewenangan Daerah tersebut.

Daerah sebagai satu kesatuan masyarakat hukum yang mempunyai otonomi berwenang mengatur dan mengurus

Daerahnya sesuai aspirasi dan kepentingan masyarakatnya sepanjang tidak bertentangan dengan tatanan hukum nasional dan kepentingan umum. Sebagai upaya memberikan ruang yang lebih luas kepada Daerah untuk mengatur dan mengurus kehidupan warganya maka Pemerintah Pusat dalam membentuk kebijakan harus memperhatikan kearifan lokal dan sebaliknya Daerah ketika membentuk kebijakan Daerah baik dalam bentuk Peraturan Daerah maupun kebijakan lainnya hendaknya juga memperhatikan kepentingan nasional. Dengan demikian akan tercipta keseimbangan antara kepentingan nasional yang sinergis dan tetap memperhatikan kondisi, kekhasan, dan kearifan lokal dalam penyelenggaraan pemerintahan secara keseluruhan.

$\begin{array}{cc}\text { Berdasarkan } & \text { konstruktif } \\ \text { yuridis normatif } & \text { partisipasi }\end{array}$
masyararakat dalam pembentukan hukum dituangkan dalam peraturan perundang-undangan. Ketentuan mengenai partisipasi publik tersebut diatur dalam:

Undang-undang No. 23 Tahun 2014, BAB XIV mengenai Partisipasi Masyarakat diuraikan dalam Pasal 354 (1) dalam 
penyelenggaraan Pemerintahan

Daerah, Pemerintah Daerah mendorong partisipasi masyarakat.

Ayat (2) dalam mendorong partisipasi masyarakat sebagaimana dimaksud pada Ayat (1), Pemerintah Daerah:

a. menyampaikan informasi tentang penyelenggaraan Pemerintahan Daerah kepada masyarakat;

b. mendorong kelompok dan organisasi masyarakat untuk berperan aktif dalam penyelenggaraan

Pemerintahan Daerah melalui dukungan pengembangan kapasitas masyarakat;

c. mengembangkan pelembagaan keputusan memungkinkan kelompok dan organisasi kemasyarakatan dapat terlibat secara efektif; dan/atau

d. kegiatan lainnya sesuai dengan ketentuan peraturan perundangundangan.

Ayat (3) Partisipasi masyarakat

sebagaimana dimaksud pada Ayat

(1) mencakup:

a. penyusunan Perda dan kebijakan Daerah yang mengatur dan membebani masyarakat;

b. perencanaan, penganggaran, pelaksanaan, pemonitoran, dan pengevaluasian pembangunan Daerah;

c. pengelolaan aset dan/atau sumber daya alam Daerah; dan penyelenggaraan pelayanan publik.
Ayat (4) Partisipasi masyarakat sebagaimana dimaksud pada Ayat

(3) dilakukan dalam bentuk:

a. konsultasi publik;

b. musyawarah;

c. kemitraan;

d. penyampaian aspirasi;

e. pengawasan; dan/atau

f. keterlibatan lain sesuai dengan ketentuan peraturan perundangundangan.

Ayat (5) Ketentuan lebih lanjut mengenai partisipasi masyarakat sebagaimana dimaksud pada Ayat (1) sampai dengan Ayat (4) diatur dengan peraturan pemerintah.

Ayat (6) Peraturan pemerintah sebagaimana dimaksud pada Ayat

(5) paling sedikit mengatur:

a. tata cara akses masyarakat terhadap informasi penyelenggaraan Pemerintahan Daerah;

b. kelembagaan dan mekanisme partisipasi masyarakat dalam penyelenggaraan Pemerintahan Daerah;

c. bentuk-bentuk partisipasi masyarakat dalam penyelenggaran Pemerintahan Daerah; dan

d. dukungan penguatan kapasitas terhadap kelompok dan organisasi kemasyarakatan agar dapat berpartisipasi secara efektif dalam penyelenggaraan Pemerintahan Daerah.

Ayat (7) Tata cara partisipasi masyarakat sebagaimana dimaksud pada Ayat (3) dan Ayat (4) diatur lebih lanjut dalam 


\section{5 | Jurnal Idea Hukum}

Vol. 5 No. 1 Maret 2019

Magister Hukum Fakultas Hukum Universitas Jenderal Soedirman

$\begin{array}{lcr}\text { Peraturan } & \text { Daerah } & \text { dengan } \\ \text { berpedoman } & \text { pada } & \text { Peraturan } \\ \text { Pemerintah. } & & \\ & & \end{array}$

3. Sikap Anggota DPRD Kabup aten Banyumas Terhadap Pa rtisipasi
Masyarakat
Dalam

Pembentukan Peraturan

Daerah No. 8 Tahun 2015

Tentang Pilkades

$\begin{array}{lrr}\text { Pasal } 1 \text { ayat (2) } & \text { Undang- } \\ \text { Undang Dasar } & \text { Negara } & \text { Republik } \\ \text { Indonesia } & \text { Tahun } & 1945 \\ \text { menyebutkan kedaulatan berada di } & \\ \text { tangan rakyat dan dilaksanakan } \\ \text { menurut Undang-Undang Dasar }\end{array}$

1945. Makna dari kedaulatan berada di tangan rakyat dalam hal ini ialah bahwa rakyat memiliki kedaulatan, tanggung jawab dan kewajiban untuk secara demokratis memilih pemimpin yang akan membentuk pemerintahan guna mengurus dan melayani seluruh lapisan masyarakat, serta memilih wakil-wakil rakyat untuk mengawasi jalannya pemerintahan.

Perwujudan kedaulatan rakyat dilaksanakan melalui pemilu secara langsung sebagai sarana bagi rakyat untuk memilih wakil-wakilnya yang akan menjalankan fungsi melakukan pengawasan, menyalurkan aspirasi politik rakyat, membuat undang-undang sebagai landasan bagi semua pihak di Negara Kesatuan Republik
Indonesia dalam menjalankan fungsi masing-masing, serta merumuskan anggaran pendapatan dan belanja untuk membiayai pelaksanaan fungsi-fungsi tersebut. Sesuai dengan ketentuan Pasal 22E ayat (6) Undang-Undang Dasar Negara Republik Indonesia Tahun 1945, pemilihan umum untuk anggota DPR, DPD dan DPRD diselenggarakan berlandaskan asas langsung, umum, bebas, rahasia, jujur dan adil, dan diselenggarakan setiap lima tahun sekali. Pemilihan Umum dimaksud diselenggarakan dengan menjamin prinsip keterwakilan, yang artinya setiap warga negara Indonesia terjamin memiliki wakil yang duduk di lembaga perwakilan, yang akan menyuarakan aspirasi rakyat di setiap pemerintahan dari pusat hingga daerah.

Motivasi seseorang menjadi anggota legislatif berkisar pada seputar keikutsertaan dalam mewakili kepentingan masyarakat banyak sehingga roda pemerintahan berjalan sebagaimana mestinya dengan memperhatikan kepentingan dan aspirasi masyarakat. Tidak jarang ditemui adanya motivasi lain yang turut menyertainya. Tentu saja motivasi tersebut harus dimurnikan agar lembaga legislatif benar-benar kembali kepada yang menyuarakan 
kepentingan rakyat. Mereka yang terpanggil menjadi anggota legislatif baik di DPR, DPD maupun DPRD selain harus memenuhi persyaratan teknis yang dibutuhkan juga perlu melengkapi dirinya dengan keinginan luhur untuk mendahulukan kepentingan rakyat di atas kepentingan pribadi dan golongannya.

Partisipasi yang berupa aspirasi dari berbagai pihak dapat dijadikan sebuah pertimbangan bagi seorang pengambil keputusan untuk memutuskan sebuah keputusan. Kearifan dalam merespon dinamika perubahan sosial merupakan landasan bagi pemerintah guna menjalankan amanat rakyat, yang dilakukan melalui kebijakan-kebijakan yang berfokus pada rakyat. Untuk itu kapasitas lembaga-lembaga pemerintahan perlu ditingkatkan untuk mendorong terwujudnya civil society yang utuh dan otonom pada masyarakat. Penyelenggaraan otonomi daerah harus selalu berorientasi pada peningkatan kesejahteraan masyarakat dengan selalu memperhatikan kepentingan dan aspirasi yang tumbuh dalam masyarakat. ${ }^{11}$

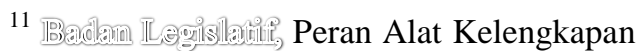
DPRD, 2008, http://baleg.wordpress.com/2008/01/18/pera n-alat-kelengkapan/, diakses pada tanggal 5 Agustus 2013.
Hasil penelitian menunjukkan bahwa dari masing-masing responden sebagai berikut: partisipasi pemuda dalam pembentukan Peraturan Daerah tentang Pilkades $50 \%$ responden menunjukkan partisipasi yang sangat tinggi, 20\% responden menunjukkan partisipasi tinggi dan $30 \%$ responden menunjukkan partisipasi cukup tinggi. Partisipasi ibu-ibu PKK/dawis terhadap perda pilkades menunjukkan sangat tinggi $29,95 \%$, responden menunjukkan partisipasi tinggi 43,54 dan responden menunjukkan partisipasi cukup tinggi 4,04\%.

Partisipasi masyarakat umum terhadap Perda pilkades $35,51 \%$ responden menunjukkan partisipasi sangat tinggi, 60,98\% responden menunjukkan partisipasi tinggi dan 2,91\% responden menunjukkan partisipasi cukup tinggi. Partisipasi tokoh ulama terhadap Perda Pilkades 42,4\% responden menunjukkan partisipasi sangat tinggi, $46,40 \%$ responden menunjukkan partisipasi tinggi dan $7 \%$ responden menunjukkan partisipasi cukup tinggi.

Anggota Dewan Perwakilan Rakyat Daerah yang menjadi responden sejumlah 3 (tiga) orang berpendapat bahwa memang partisipasi masyarakat sangat dibutuhkan, terutama dalam bentuk 


\section{7 | Jurnal Idea Hukum}

Vol. 5 No. 1 Maret 2019

Magister Hukum Fakultas Hukum Universitas Jenderal Soedirman

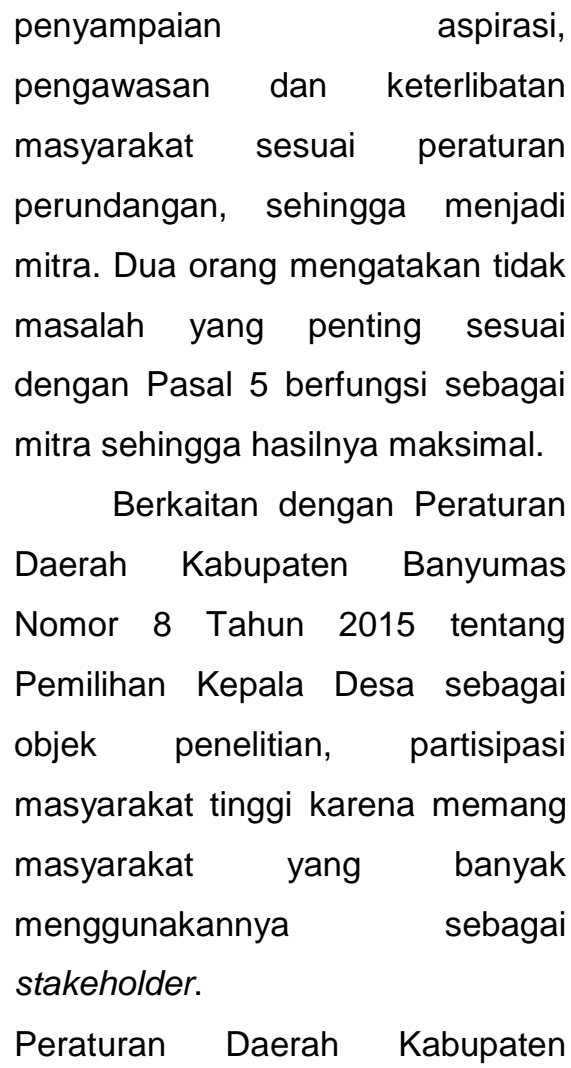

Banyumas No. 8 Tahun 2015, pada

Pasal 3:

Ayat 1 menyebutkan Bupati membentuk Tim Fasilitasi Pemilihan Kepala Desa tingkat Kabupaten dengan keanggotaan unsur Muspida dan Lemtekda/Dinas/Instansi/ Bagian terkait.

Ayat 2 disebutkan bahwa Camat membentuk Tim Fasilitasi Pemilihan Kepala Desa tingkat Kecamatan dengan keanggotaan unsur Kecamatan, Koramil dan Kepolisian sektor setempat.

Ayat 3 Tim Fasilitasi Pemilihan Kepala Desa tingkat Kabupaten sebagaimana dimaksud pada ayat (1), mempunyai tugas:

a. memfasilitasi penyelenggaraan Pemilihan Kepala Desa di Kabupaten Banyumas agar berjalan dengan lancar, tertib dan aman;

b. menyusun petunjuk

pelaksanaan dan

petunjuk teknis

pemilihan Kepala Desa;

c. mengkoordinasikan

pelaksanaan pemilihan

Kepala Desa;

d. mengkoordinasikan pengamanan Pemilihan Kepala Desa;

e. melakukan pemantauan pelaksanaan Pemilihan Kepala Desa sejak persiapan sampai dengan Pelantikan Kepala Desa terpilin;

f. memberikan saran dan bimbingan kepada Tim Fasilitasi Pemilihan Kepala Desa tingkat Kecamatan dan/atau Panitia Pemilihan dan/atau Panitia Pengawas di tingkat Desa;

g. memberikan saran dan pertimbangan kepada Bupati dalam pengambilan Keputusan;

h. melaporkan kepada Bupati Banyumas atas pelaksanaan tugasnya.

Ayat 4 mengatur tentang Tim Fasilitasi Pemilihan Kepala Desa tingkat Kecamatan sebagaimana dimaksud pada ayat (2), mempunyai tugas:

a. memfasilitasi penyelenggaraan Pemilihan Kepala Desa di Kecamatan masingmasing agar berjalan dengan lancar, tertib dan aman;

b. memfasilitasi

pengamanan dan mengambil langkahlangkah yang diperlukan apabila terjadi gangguan keamanan 
sejak persiapan sampai dengan selesainya kegiatan Pemilihan Kepala Desa;

c. memfasilitasi pembentukan Panitia Pemilihan dan Panitia Pengawas tingkat Desa;

d. memfasilitasi penyusunan tata tertib pemilihan Kepala Desa;

e. memberikan saran dan bimbingan kepada Panitia Pemilihan dan/atau Panitia Pengawas tingkat Desa;

f. memberikan saran dan pertimbangan dibidang keamanan kepada Bupati;

g. melaporkan kepada Camat atas pelaksanaan tugasnya yang selanjutnya Camat meneruskan laporan tersebut kepada Bupati.

Pasal tersebut mengatur secara teknis pelaksanaan Pemilihan Kepala Desa yang sangat diperlukan untuk dimintakan partisipasi masyarakat. Masyarakat yang akan melakukan pemilihan, bukan mereka yang di Kabupaten/Kota, dimana masyarakat tidak hanya terdiri dari orang tua (orang yang dituakan), laki-laki, perempuan, remaja/pemuda dll. sehingga sangat membutuhkan partisipasi. Pada sisi lain harus disadari bahwa dengan partisipasi masyarakat tugas yang tambah berat bagi anggota DPRD adalah menentukan sikap untuk menerima partisipasi mereka.

Pemilihan Kepala Desa menggunakan Asas langsung, dimaknai bahwa warga masyarakat desa yang sudah memenuhi persyaratan sebagai pemilih secara langsung (dirinya sendiri) melaksanakan pemilihan dan menjatuhkan pilihannya kepada salah seorang Calon yang Berhak Dipilih sesuai yang dikehendaki. Asas umum, dimaknai bahwa warga masyarakat desa yang sudah memenuhi persyaratan sebagai pemilih sebagaimana diatur dalam Peraturan Daerah ini dapat menggunakan hak pilihnya untuk memilih salah satu dari beberapa Calon yang Berhak Dipilih. Asas bebas, dimaknai bahwa warga masyarakat desa yang sudah memenuhi persyaratan sebagai pemilih diberikan keleluasaan dan kebebasan untuk menentukan pilihannya kepada salah satu dari beberapa Calon yang Berhak Dipilih sesuai dengan pilihan hati nuraninya.

Asas rahasia, dimaknai bahwa pilihan dari warga masyarakat yang sudah memenuhi persyaratan sebagai pemilih dalam menjatuhkan pilihannya dijamin kerahasiaan pilihannya. Dalam artian pilihan yang dipilihnya hanya 
1399 | Jurnal Idea Hukum

Vol. 5 No. 1 Maret 2019

Magister Hukum Fakultas Hukum Universitas Jenderal Soedirman

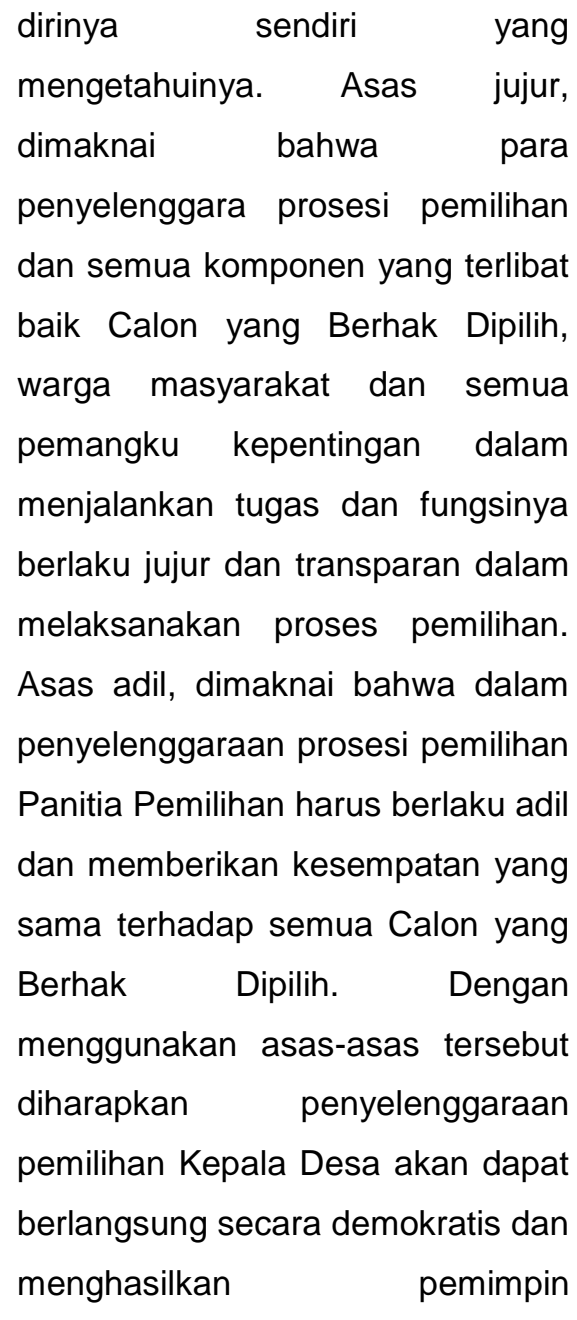

Pemerintah Desa yang berkualitas.

Penjabat Kepala Desa
adalah Kepala Desa sementara
yang diangkat dan diberi tugas
utama oleh Bupati untuk
melaksanakan Pemilihan Kepala
Desa serta mempunyai tugas, hak,
wewenang dan kewajiban Kepala
Desa yang sama dengan Kepala
Desa definitif dalam kurun waktu
tertentu. Dalam kurun waktu
tertentu masyarakat dapat
mengikuti berjalannya Peraturan
Daerah yang berlaku dan bilamana

terdapat hal-hal yang kurang tepat dapat diperbaiki kemudian.

Peran Dewan Perwakilan Rakyat Daerah pada dasarnya menyangkut masyarakat, dimana masyarakat bisa menjadi bagian dari jalannya pemerintahan yang ada. Peran Dewan Perwakilan Rakyat Daerah dalam membangun dan meningkatkan partisipasi masyarakat melalui pola-pola penyerapan aspirasi masyarakat yang digunakan selama ini, tidak hanya mengacu pada aturanaturan/ kaidah hukum yang berlaku, namun banyak menggunakan berbagai cara yang dinilai cukup efektif, ini untuk lebih memudahkan anggota Dewan Perwakilan Rakyat Daerah dalam mendapatkan ataupun memperoleh aspirasi masyarakat dari berbagai lapisan masyarakat. Hal ini berarti bahwa peran Dewan Perwakilan Rakyat Daerah haruslah selalu mengutamakan kepentingan masyarakat luas, dimana masyarakat tidak hanya sebagai objek melainkan subjek atau pelaku dari pemerintah yang ada.

\section{Kesimpulan}

Peran Dewan Perwakilan Rakyat Daerah dalam membangun dan meningkatkan partisipasi masyarakat melalui pola-pola penyerapan aspirasi masyarakat digunakan selama ini, tidak 
hanya mengacu pada aturanaturan/kaidah hukum yang berlaku, namun banyak menggunakan berbagai cara yang dinilai cukup efektif. Hal ini untuk lebih memudahkan anggota Dewan Perwakilan Rakyat Daerah dalam mendapatkan ataupun memperoleh aspirasi masyarakat dari berbagai lapisan masyarakat. Tindakan aktif anggota DPRD dilakukan melalui Focus Grup Discussion, media elektronik, media cetak, bahkan pernah dilakukan dengan pendekatan individual, mengingat anggota DPRD merasa bahwa masyarakat adalah mitra mereka.

\section{Daftar Pustaka}

Davis, Keith, 2000, Perilaku Dalam Organisasi, Edisi ketujuh, Jakarta: Erlangga

Soetrisno 2000, Menuju Masyarakat Partisipatif, Yogyakarta: Kanisius.

Sumaryadi, I Nyoman, 2005, Efektivitas Implementasi Kebijkan Otonomi Daerah, Jakarta: Citra Utama.

Yuwono, Teguh, 2001, Manajemen Otonomi Daerah : Membangun Daerah Berdasarkan Paradigma Baru, Semarang: Ciyapps Diponegoro Universiti.

Badan Legislatifin Peran Alat Kelengkapan DPRD, 2008, http://baleg.wordpress.com/2008/01 /18/peran-alat-kelengkapan/, diakses pada tanggal 5 Agustus 2013.

Kementerian Hukum dan Hak Asasi Manusia Republik Indonesia, Direktorat Jenderal Peraturan Perundang-undangan, Direktorat Fasilitasi Perancangan Peraturan Daerah, 2011, Panduan Praktis Memahami Perancangan Peraturan Daerah Edisi Kelima, Direktorat
Jenderal Peraturan Perundangundangan, Jakarta.

Tim Peneliti Universitas Hasanuddin, 2009, Hasil Penelitian: Esensi Dan Urgensitas Peraturan Daerah Dalam Pelaksanaan Otonomi Daerah, Universitas Hasanuddin bekerjasama dengan Dewan Perwakilan Daerah Republik Indonesia, Makasar. 